\title{
STRATEGI PENINGKATAN KINERJA SUMBER DAYA MANUSIA PADA PERUSAHAAN KONSTRUKSI PT. JAYA KUSUMA SARANA BALI MELALUI PENDEKATAN BUDAYA ORGANISASI

\author{
Ni Made Sintya Rani ${ }^{1}$, GAP. Candra Dharmayanti ${ }^{2}$, I B. Rai Adnyana ${ }^{2}$
}

\begin{abstract}
Abstrak : Salah satu kunci mencapai keberhasilan suatu perusahaan Kontraktor dalam mencapai visi dan misinya adalah kualitas Sumber Daya Manusia (SDM) yang baik. Dari hasil evaluasi ISO 9001, kualitas SDM yang diukur pada PT. Jaya Kusuma Bali (PT. JKS Bali) berdasarkan indikator sasaran dan target dari tiap divisi disimpulkan bahwa kualitas SDM masih perlu ditingkatkan. Dengan mengetahui gambaran Budaya Organisasi saat ini (existing) dan yang diinginkan (preferred) maka dapat diketahui strategi yang diperlukan suatu organisasi untuk mencapai visi dan misinya. Penelitian ini bertujuan untuk mengetahui profil budaya saat ini dan yang diinginkan berdasarkan persepsi dari karyawan PT. JKS Bali dan strategi apa yang diperlukan untuk meningkatkan kualitas SDM PT. JKS Bali.

Metode yang digunakan adalah metode analisi OCAI (Organizational Culture Assessment Instrument) dan survai menggunakan kuesioner OCAI. Metode ini dipergunakan untuk memperoleh gambaran budaya organisasi saat ini (current) dan budaya yang diinginkan dimasa yang akan datang (preferred) yang penilaiannya diukur dalam 6 dimensi utama (karakteristik dominan, kepemimpinan organisasi, pengelolaan karyawan, perekat organisasi, penekanan strategis dan kriteria sukses) yang kemudian dapat memetakan tipe profil budaya organisasi (Clan Culture, Adhocracy Culture, Market Culture dan Hierarchy Culture).

Hasil analisis menunjukan Profil Budaya Organisasi pada PT. JKS Bali saat ini (current) dan Budaya Organisasi yang diharapkan (preferred) tidak membutuhkan perubahan yang siginifikan. Strategi yang ditempuh untuk menunjang peningkatan kualitas SDM berdasarkan keenam dimensinya adalah dengan menerapkan kepemimpinan organisasi yang lebih fleksible namun tidak juga melanggar aturan, Melakukan pengelolaan karyawan yang mengutamakn kerja sama tim, Mengurangi formalitas prosedur kerja, fokus pada internal perusahaan, menekankan pengembangan SDM dan komitmen kerja.
\end{abstract}

\section{PERFORMANCE IMPROVEMENT STRATEGIES OF HUMAN RESOURCES AT PT. JAYA KUSUMA SARANA BALI CONSTRUCTION COMPANY THROUGH ORGANIZATIONAL CULTURE APPROACH}

\begin{abstract}
One of the key success factors of a contractor company in achieving their vision and mission is good quality of human resources (HR). Based on ISO 9001 evaluation, the quality of HR at PT. Jaya Kusuma Sarana Bali (PT.JKS Bali) that measured by indicators of objectives and targets from each division concluded that the quality of HR still need to be improved. By knowing the profile of the current and preferred organizational culture, it can be identified the strategy required to achieve the vision and mission of the organization. This study aimed to analyze the culture profile of PT. JKS Bali based on their employees perception, in order to identify strategies for improving their HR performance.

The method used is an OCAI (Organizational Culture Assessment Instrument) analysis method and a survey using the OCAI questionnaire. The analysis involved identification of the culture profiles that measured in 6 key dimensions (i.e.: Dominant Characteristics, Organizational Leadership, Management of Employees, Organization Glue, Strategic Emphases and Criteria of Success) which can represent the four culture types of an organization (i.e.: Clan, Adhocracy, Market dan Hierarchy).

The result suggests that the profile of the current and preferred organizational culture at PT.JKS Bali does not require significant changes. The strategies that need to be implemented derived from six key dimensions, Applying more flexible organizational leadership but also against the rules, Managing the employees who prioritize teamwork, Reducing formalities working procedures, focusing on the company's internal, emphasizing human resource development and employment commitments.
\end{abstract}

Keywords : Strategy, improvement, human resource, contractor, OCAI

\footnotetext{
${ }^{1}$ Mahasiswa Program Magister Teknik Sipil, Program Pascasarjana, Universitas Udayana, Denpasar

${ }^{2}$ Staf Pengajar Program Magister Teknik Sipil, Program Pascasarjana, Universitas Udayana, Denpasar
} 


\section{PENDAHULUAN}

\section{Latar Belakang}

Banyaknya kontraktor yang saat ini bermunculan serta pesatnya pembangunan di Bali mendorong para kontraktor untuk saling berkompetensi secara ketat untuk memberikan kualitas yang terbaik.

Dalam hal ini Sumber Daya Manusia (SDM) merupakan kunci menuju keberhasilan suatu perusahaan, dan untuk meningkatkan kualitas SDM manajemen wajib melakukan perekrutan orang-orang yang mampu dibidangnya, melakukan pelatihan dan pengembangan kemampuan serta menciptakan lingkungan kerja atau budaya kerja yang baik dan supportive sebagai cara meningkatkan motivasi kerja.

PT. Jaya Kusuma Sarana Bali merupakan salah satu perusahaan kontraktor swasta yang menawarkan jasa pelaksanaan konstruksi. Kompetensi yang dimiliki PT. Jaya Kusuma Sarana Bali dalam bidang konstruksi adalah mengerjakan proyek konstruksi struktural dan arsitektural. Ketatnya persaingan yang terjadi antara para kontraktor dan sering terjadinya pergantian personel dalam perusahaan mempengaruhi kualitas SDM pada perusahaan. Berdasarkan hasil evaluasi ISO 9001, kualitas SDM yang diukur berdasarkan indikator sasaran dan target dari tiap divisi dapat disimpulkan bahwa kualitas SDM di PT. Jaya Kusuma Sarana Bali masih perlu ditingkatkan (PT. JKSB, 2013).

Cameron dan Quinn (2011) menyatakan hal yang membedakan organisasi yang sukses terhadap yang lain adalah terletak pada budaya organisasinya. Dengan mengetahui gambaran budaya organisasi saat ini (existing) dan yang diinginkan (preferred), maka dapat diketahui strategi yang diperlukan suatu organisasi untuk mencapai visi dan misinya. Guna menunjang penerapan strategi peningkatan kualitas SDM pada perusahaan ini, penelitian dilakukan dengan menggunakan metode survai OCAI (Organizational Culture Assessment Instrument) yang dikembangkan oleh Cameron dan Quinn (2011) untuk melakukan pemetaan budaya organisasi pada saat ini dan yang akan datang.

\section{Rumusan Masalah}

1. Bagaimana profil Budaya Organisasi saat ini (current) danyang diharapkan (preferred) berdasarkan persepsi dari karyawan PT. Jaya Kusuma Sarana Bali ?
2. Strategi apa yang diperlukan untuk meningkatkan kualitas Sumber Daya Manusia pada PT. Jaya Kusuma Sarana Bali ?

\section{Tujuan Penelitian}

1. Untuk mengetahui profil Budaya Organisasi saat ini (current) dan yang diharapkan (preferred) berdasarkan persepsi dari karyawan PT. Jaya Kusuma Sarana Bali

2. Untuk mengetahui Strategi apa yang diperlukan untuk meningkatkan kualitas Sumber Daya Manusia pada PT. Jaya Kusuma Sarana Bali

\section{KAJIAN PUSTAKA \\ Manajemen Sumber Daya Manusia}

Manajemen Sumber Daya Manusia yaitu suatu metode pengelolaan sumber daya manusia didalam sebuah organisasi agar mampu mencapai tujuan dari organisasi secara maksimal melalui pengembangan sumber daya manusia itu sendiri

\section{Pengelolaan SDM}

Menurut Ed's (2008) mengelola SDM perusahaan pada dasarnya merupakan kegiatan perusahaan dalam mengelola para pegawainya (SDM). Pengelolaan dimulai dari rekrutmen yang meliputi perencanaan SDM, analisa jabatan yang menentukan pekerjaan serta jabatan yang pantas, seleksi, pelatihan dan pengembangan, penilaian prestasi kerja, pemberian kompensasi, serta pembaharuan yang berhubungan dengan pensiun dan pemberhentian kerja. Dalam pengelolaan SDM guna meningkatkan kualitas suatu perusahaan dapat dilakukan dengan meningkatkan kinerja dari SDM itu sendiri, maka perlu diketahui lebih lanjut mengenai peningkatan SDM.

\section{Peningkatan Kualitas SDM}

Kualitas Sumber Daya Manusia adalah sumber daya yang memiliki kompetensi baik dari aspek fisik maupun aspek intelektual. Berdasarkan pengertian diatas peningkatan kualitas Sumber Daya manusia dapat dilakukan dengan cara :

a. Peningkatan kualitas fisik dapat diupayakan melalui program kesehatan dan gizi

b. Peningkatan kualitas kemampuan non fisik dapat dilakukan dengan pelatihan (training), seminar dan workshop. 


\section{Hubungan Peingkatan Kualitas SDM dengan Kinerja SDM}

Kualitas SDM merupakan masalah utama yang patut mendapat perhatian organisasi, karena kualitas SDM dipandang mampu untuk meningkatkan peran serta anggota atau karyawan terhadap organisasi. Kualitas SDM mempunyai pengaruh positif dan signifikan terhadap kinerja perusahaan. Adanya kualitas SDM juga meumbuhkan keinginan para karyawan untuk tetap tinggal dalam organisasi (Husnawati, 2006). Pada penelitin menunjukan adanya hubungan positif antara kualitas SDM dengan kinerja karyawan (Elmuti dan Kathawala, 1997 dalam Husnawati, 2006)

\section{Peningkatan Kinerja SDM}

Dalam meningkatkan kinerja SDM manajemen harus selalu mencari, mengembangkan dan mempertahankan SDM yang sesuai dengan kebutuhan. Terdapat tiga strategi dalam perencanaan SDM, yaitu (Alwi, 2012) :

1. Perencanaan SDM dan Orientasi Strategik.

2. Tahap perencanaan taktikal SDM

3. Perencanaan Operasional SDM

\section{Budaya Organisasi}

Budaya Organisasi adalah pengertian dari kata budaya dan organisasi itu sendiri, menurut beberapa ahli pengertian dari budaya organisasi disimpulkan bahwa budaya organisasi adalah sistem nilai organisasi yang dianut oleh anggota organisasi yang kemudian mempengaruhi cara bekerja dan berperilaku dari para anggota organisasi. Selain pengertian terdapat pula jenis-jenis budaya organisasi, Jenis - jenis Budaya Organisasi dibagi menjadi dua yaitu bedasarkan proses informasi dan berdasarkan tujuannya. Berdasarkan proses informasi :

1. Budaya Rasional

2. Budaya Ideologis

3. Budaya Konsensus

4. Budaya Hirarkies

Berdasarkan tujuannya Ndraha (1997) dalam Tika (2014) :

1. Budaya Organisasi perusahaan

2. Budaya Organisasi publik

3. Budaya Organisasi sosial

\section{Pengaruh Budaya Organisasi terhadap peningkatan kinerja}

Budaya organisasi memiliki pengaruh terhadap peningkatan kinerja suatu organisasi atau perusahaan, hal ini dikemukakan oleh Kotter dan Heskett (1992) dalam Tika (2014).
Ada empat kesimpulan yang dikemukakan yaitu :

1. Budaya perusahaan dapat mempunyai dampak yang berarti terhadap kinerja ekonomi jangka panjang.

2. Budaya perusahaan mungkin akan menjadi suatu faktor yang bahkan lebih penting lagi dalam menentukan keberhasilan atau kegagalan perusahaan dalam dasawarsa yang akan datang.

3. Budaya perusahaan yang menghambat kinerja keuangan jangka panjang mudah berkembang dalam perusahaan yang penuh dengan orang-orang pandai dan berakal sehat.

4. Budaya perusahaan dapat diubah agar bersifat lebih meningkatkan kinerja.

Dalam mendukung kesimpulan tersebut Kotter dan Hesket (1992) dalam Tika (2014) mengemukakan tiga teori, yaitu :

1. Budaya yang kuat berkaitan dengan kinerja yang unggul

2. Budaya secara strategis cocok

3. Budaya yang adatif

\section{Model dan Karakteristik dalam} membangun Budaya Organisasi

Ada berbagai model budaya organisasi yang dikembangkan oleh para peneliti baik secara kualitatif maupun kuantitaif untuk dapat memahami budaya organisasi antara lain :

1. Hofstede (2012) mengidentifikasikan 7 dimensi budaya organisasi

a. Power Distance

b. Uncertainty avoidance

c. Individualism vs collectivism

d. Masculinity vs femininity

e. Long vs short term orientation

f. Monumentalism vs flexumility

g. Indulgence vs Restrain

2. O'Reilly Chatman dan Cadwell (1991) dalam Tjahyanti (2011) pada Teori Organizational Culture Profile (OCP) menyatakan budaya organisasi memiliki 7 karakteristik yaitu :

a. Innovation and risk taking

b. Attention to detail

c. Outcome orientation

d. People orientation

e. Team orientation

f. Aggressiveness

g. Stability, Nagel (2006) menambahkan karakteristik yang ke-8,

h. Agility

3. Cameron dan Quinn (2011) melalui pendekatan OCAI (Organization Culture Assessment Instrument) terdapat 4 tipe profil budaya organisasi : 
a. Clan Culture

b. Adhocracy Culture

c. Market Culture

d. Hierarchy Culture

Jenis kecenderungan budaya organisasi tersebut dapat diilustrasikan dalam Competing Values Framework (CVF) seperti gambar berikut :

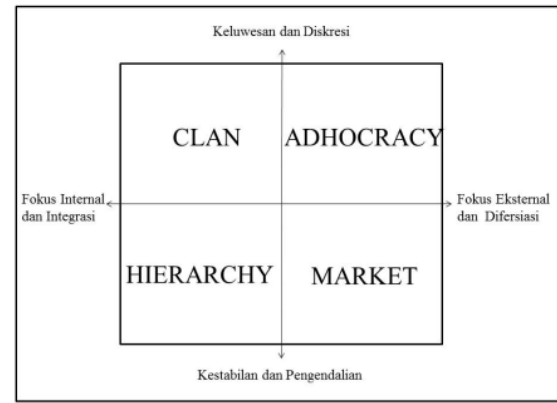

Gambar 1

Jenis Budaya Organisasi dalam Competing Values Framework

Cameron dan Quinn lebih lanjut mengembangkan OCAI dengan membedakan menggunakan enam dimensi Budaya organisasi yaitu Karakteristik dominan, Kepemimpinan Organisasi, Pengelolaan Karyawan, Perekat organisasi, Penekanan Strategis, Kriteria Sukses. Pada kecenderungan Budaya Organisasi saat ini (current) dan yang diinginkan di masa yang akan datang (preferred) terdapat perbedaan atau gap. Signifikasi perbedaan Budaya Organisasi saat ini (current) dan yang diinginkan (preferred) sebesar plus atau minus lebih besar dari 5\% menunjukan perlunya upaya perubahan besar. (Cameron dan Quinn, 2011)

4. Shein (2004) menyatakan budaya organisasi terdiri dari 3 tingkatan :
a. Artifacts
b. Aspoused Values
c. Basic Underlying

\section{Uji Validitas dan Reliabilitas}

1. Uji Reliabilitas

Reliabel berarti sejauh mana instrument penelitian ini konsisten, yaitu setiap dilakukan pengujian terhadap kuesioner hasilnya tetap konsisten. Beberapa studi telah menguji reliabilitas dari instrument OCAI, yaitu oleh Quinn dan Spreitzer (1991), Yeung, Brockbank dan Ulrich (1991), Zammuto dan Krakower (1991), Peterson, Cameron, Spencer dan White (1991). Dari setiap studi yang serupa reliabilitas menunjukan pola yang konsisten, dengan kata lain instrument OCAI reliable.
2. Uji Validitas

Validitas mempunyai arti sejauh mana ketepatan dan kecermatan suatu alat ukur dalam melakukan fungsi ukurnya. Artinya apakah instrument ini benar - benar tepat dalam mengukur empat tipe budaya organisasi yang ada dalam suatu organisasi. Seperti halnya uji reliabilitas, hal yang sama juga dilakukan dalam uji validitas yaitu oleh Cameron dan Freeman (1991), Quinn dan Spreitzer (1991), Zammuto dan Krakower (1991). Berdasarkan pengalaman penelitian diatas instrument OCAI merupakan instrument yang valid dan reliable.

\section{METODE PENELITIAN \\ Rancangan Penelitian}

Rancangan Kegiatan penelitian yang dilakukan adalah studi pendahuluan yaitu pengamatan mengenai kinerja SDM pada perusahaan, kemudian mengidentifikasikan masalah, menentukan tujuan penelitian, melakukan pengumpulan data yaitu data primer yang merupakan data dari hasil survai degan menggunakan kuesioner OCAI kepada karyawan PT. JKS Bali dan data skunder yaitu data penunjang berupa latar belakang perusahaan, struktur organisasi, visi misi, serta jumlah karyawan di PT. JKS Bali yang diperoleh dari divisi HRD. Secara sistematis kerangka penelitian dijelaskan pada Gambar berikut:

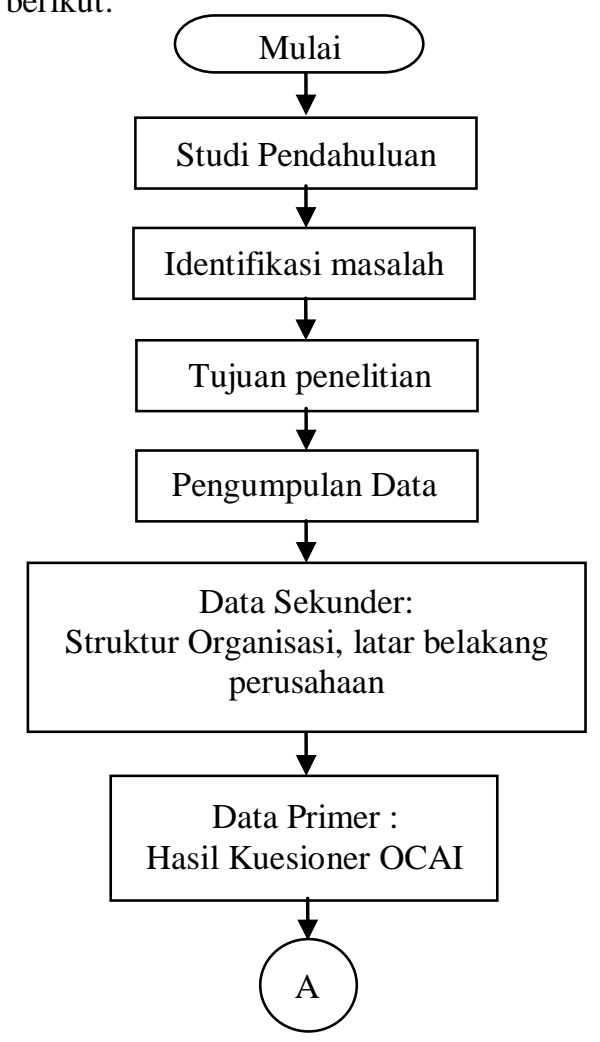




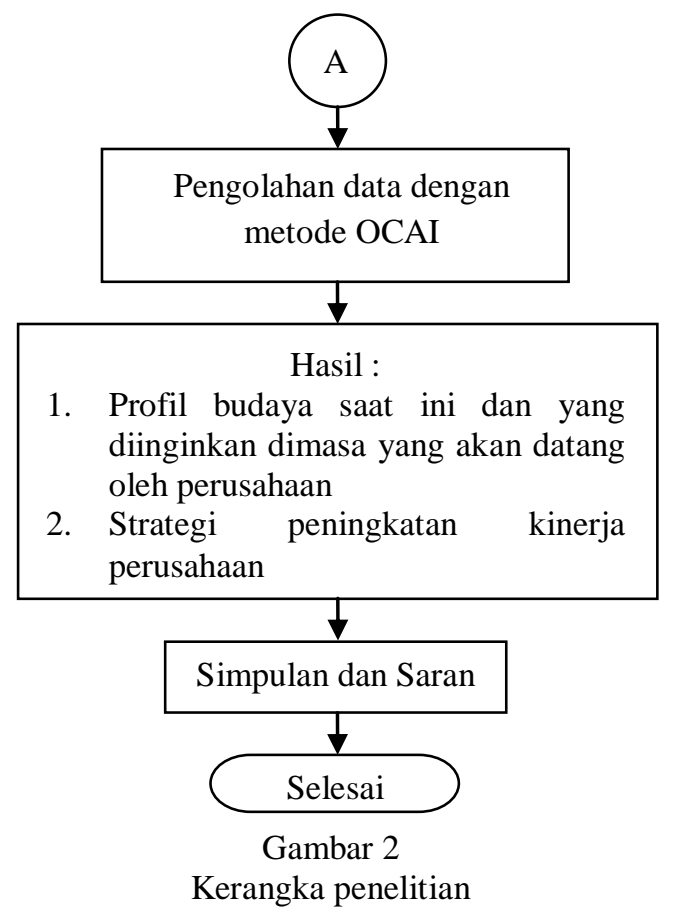

Uji Reliabilitas dan Uji Validitas

berdasarkan hasil penelitian uji reliabilitas pada kuesioner OCAI memperoleh nilai konsisten $\alpha>0,5$ dan serupa untuk uji validitas mendapatkan nilai koefisioen korelasi lebih besar dari nol.

\section{Lokasi dan Waktu Penelitian}

Penentuan lokasi penelitian dilakukan di Kantor PT. Jaya Kusuma Sarana Bali yang beralamat di Jalan Imam Bonjol, Pertokoan Imam Bonjol Square block AA 20-21. Waktu pelaksanaan survai dilakukan pada jam istirahat karyawan pukul 12.00 sampai dengan pukul 14.00 dan dilakukan dalam beberapa kali penyebaran kuesioner.

\section{Sumber Data}

Sumber data pada penelitian ini adalah seluruh karyawan PT. JKS Bali dengan jumlah sebanyak 142 pekerja termasuk pegawai kantor dan proyek. Penentuan sample menggunakan metode non-probability method yaitu purposive sampling. Menurut Ulwan (2014) Purposive sampling adalah pengambilan sample secara sengaja dengan persyaratan sample yang diperlukan (sifatsifat, karakteristik, ciri, kriteria) yang tetap mencerminkan populasi. Kriteria dalam pengambilan sample yaitu staff atau staff dengan posisi setingkat manajer dengan pengalaman kerja lebih dari 10 tahun, maka diperoleh jumlah sample sebanyak 29 karyawan.

\section{Instrumen Penelitian}

Instrumen penelitian pada penelitian ini adalah menggunakan Kuesioner OCAI (Organization Change Assesment Instrumen) yang dikembangkan oleh Cameron dan Quinn (2011). Skala yang digunakan adalah skala ipsative yang merupakan skala yang membagi 100 poin antara alternative yang ada serta merupakan keterangan yang digunakan untuk menentukan ukuran di mana responden membandingkan dua atau lebih pilihan yang diinginkan dan memilih salah satu yang paling disukai (Cameron and Quinn, 2011).

\section{Analisis dan Pengelohan Data}

Dilakukan pengolahan dan analisis data dengan menggunakan metode OCAI (Organizational Culture Assesment Instrument) dimana metode pengolahan data ini dibantu dengan menggunakan program Microsoft excel 2007. Setelah memperoleh data hasil survey dengan kuesioner OCAI dilakukan validitas data hasil survai, kemudian dibuat rekap dari hasil kuesioner tersebut dalam bentuk table yang dibagi atas 6 dimensi budaya. Salah satu contoh table dominant characteristic sepeti table dibawah

Tabel 1

Tabel contoh rekap kuesioner OCAI Dominant Characteristic

\begin{tabular}{|c|c|c|c|c|c|c|c|c|c|c|c|}
\hline & \multirow{3}{*}{$\begin{array}{l}\text { Respo } \\
\text { nden }\end{array}$} & \multicolumn{9}{|c|}{ Karakteristik Dominan } & \\
\hline \multirow{2}{*}{$\begin{array}{l}\mathrm{N} \\
\mathrm{o}\end{array}$} & & \multicolumn{4}{|c|}{ Current } & \multirow{2}{*}{$\begin{array}{c}\mathrm{Su} \\
\mathrm{m}\end{array}$} & \multicolumn{4}{|c|}{ Preferred } & \multirow[b]{2}{*}{ Sum } \\
\hline & & $\mathrm{A}$ & $\mathrm{B}$ & $\mathrm{C}$ & $\mathrm{D}$ & & $\mathrm{A}$ & B & $\mathrm{C}$ & $\mathrm{D}$ & \\
\hline 1 & R1 & 20 & 30 & 40 & 10 & 100 & 50 & 20 & 10 & 20 & 100 \\
\hline 2 & $\mathrm{R} 2$ & 10 & 30 & 50 & 10 & 100 & 40 & 30 & 10 & 20 & 100 \\
\hline 3 & $\mathrm{R} 3$ & 20 & 20 & 50 & 10 & 100 & 40 & 20 & 20 & 20 & 100 \\
\hline \multicolumn{2}{|c|}{ Rata-rata } & $\begin{array}{c}16, \\
7\end{array}$ & $\begin{array}{c}26, \\
6\end{array}$ & $\begin{array}{c}46, \\
7\end{array}$ & 10 & 100 & $\begin{array}{c}43, \\
3\end{array}$ & $\begin{array}{c}23 \\
4\end{array}$ & $\begin{array}{c}13, \\
3\end{array}$ & 20 & 100 \\
\hline \multicolumn{2}{|c|}{ Input value } & 17 & 26 & 47 & 10 & 100 & 43 & 24 & 13 & 20 & 100 \\
\hline
\end{tabular}

Dari nilai input value dapat dibuat sebuah chart dengan tipe radar seperti pada gambar berikut :

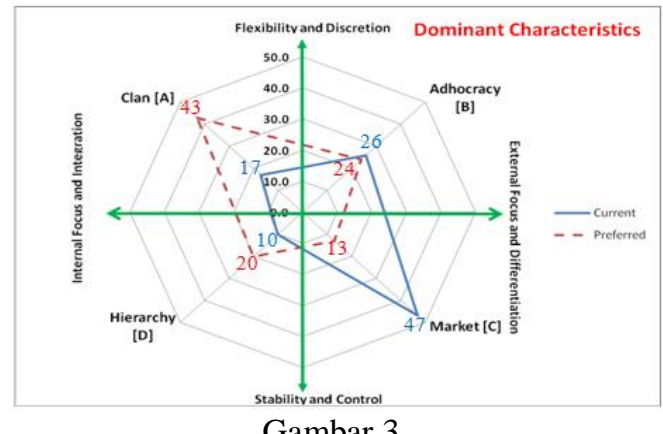

Contoh chart OCAI Dominant Characteristic

\section{HASIL DAN PEMBAHASAN \\ Validasi Data Hasil Survai}

Berdasarkan hasil penyebaran kuesioner kepada responden, maka diperoleh rekap penilaian responden terhadap setiap pertanyaan untuk enam dimensi budaya 
organisasi pada PT.JKS Bali. Dari hasil tersebut dilakukan validitas data, yang meliputi screening terhadap data yang ekstreme atau outlier. Identifikasi terhadap data ekstrem dengan menggunakan boxplot dalam SPSS ditemukan adanya data outlier pada table dibawah :

Tabel 2

Data Outlier hasil survai PT.JKS Bali

\begin{tabular}{|c|c|c|c|c|c|}
\hline $\begin{array}{c}\text { Respon } \\
\text { den }\end{array}$ & $\begin{array}{c}\text { Jumlah } \\
\text { Outlier }\end{array}$ & $\begin{array}{c}\text { Respon } \\
\text { den }\end{array}$ & $\begin{array}{c}\text { Jumlah } \\
\text { Outlier }\end{array}$ & $\begin{array}{c}\text { Respon } \\
\text { den }\end{array}$ & $\begin{array}{c}\text { Jumlah } \\
\text { Outlier }\end{array}$ \\
\hline R1 & 2 & R11 & 2 & R21 & 0 \\
\hline R2 & 0 & R12 & 11 & R22 & 1 \\
\hline R3 & 6 & R13 & 0 & R23 & 0 \\
\hline R4 & 1 & R14 & 1 & R24 & 1 \\
\hline R5 & 1 & R15 & 0 & R25 & 1 \\
\hline R6 & 0 & R16 & 3 & R26 & 1 \\
\hline R7 & 2 & R17 & 0 & R27 & 0 \\
\hline R8 & 2 & R18 & 0 & R28 & 0 \\
\hline R9 & 0 & R19 & 3 & R29 & 0 \\
\hline R10 & 3 & R20 & 1 & & \\
\cline { 1 - 2 } Sumb &
\end{tabular}

Sumber : Analisis OCAI, 2015

\section{Data Hasil Survai}

Berdasarkan hasil validasi data hasil survai kuesioner kepada responden, maka diperoleh rekap rata-rata penilaian responden terhadap setiap pertanyaan untuk enam dimensi budaya organisasi pada pada PT. JKS Bali pada table dibawah :

Tabel 3

Rekap Rata-rata hasil survai PT. JKS Bali

\begin{tabular}{|c|l|c|c|c|c|c|c|c|c|}
\hline \multirow{2}{*}{ No } & \multirow{2}{*}{$\begin{array}{l}\text { Dimensi Budaya } \\
\text { Organisasi }\end{array}$} & \multicolumn{4}{|c|}{ Saat ini (\%) } & \multicolumn{4}{|c|}{ Yang diharapkan (\%) } \\
\cline { 3 - 10 } & & A & B & C & D & A & B & C & D \\
\hline 1 & $\begin{array}{l}\text { Karakteristik } \\
\text { Dominan }\end{array}$ & 16 & 16 & 34 & 34 & 19 & 16 & 35 & 30 \\
\hline 2 & $\begin{array}{l}\text { Kepemimpinan } \\
\text { Organisasi }\end{array}$ & 19 & 22 & 27 & 33 & 20 & 23 & 30 & 28 \\
\hline 3 & $\begin{array}{l}\text { Pengelolaan } \\
\text { Karyawan }\end{array}$ & 21 & 20 & 25 & 34 & 27 & 20 & 21 & 32 \\
\hline 4 & $\begin{array}{l}\text { Perekat } \\
\text { Organisasi }\end{array}$ & 22 & 22 & 26 & 30 & 26 & 24 & 25 & 25 \\
\hline 5 & $\begin{array}{l}\text { Penekanan } \\
\text { Strategis }\end{array}$ & 20 & 19 & 30 & 31 & 23 & 21 & 25 & 31 \\
\hline 6 & Kriteria Sukses & 20 & 20 & 29 & 30 & 25 & 21 & 28 & 26 \\
\hline 7 & $\begin{array}{l}\text { Profil } \\
\text { Keseluruhan }\end{array}$ & 20 & 20 & 29 & 32 & 23 & 21 & 27 & 29 \\
\hline
\end{tabular}

Notasi : A = Clan; B = Adhocracy; C =Market; $\mathrm{D}=$ Hirearchy

Sumber : Analisis OCAI, 2015

\section{Profil Budaya Organisasi PT. JKS Bali}

Dari nilai rekap rata-rata hasil survey dibuat diagram dalam bentuk radar untuk memetakan tipe budaya organisasi yang ada pada saat ini dan yang diinginkan dari PT JKS seperti gambar dibawah : a. Karakteristik dominan

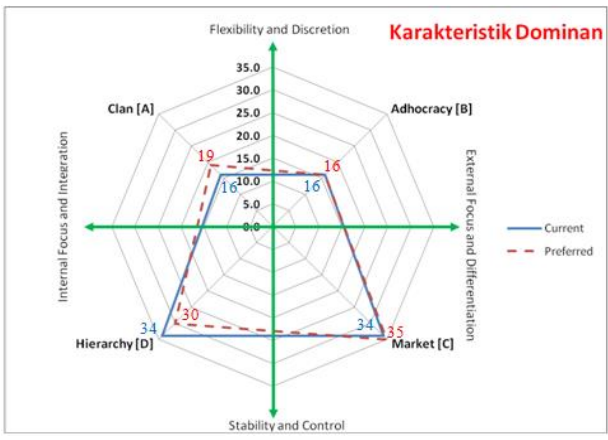

Gambar 4

Diagram Radar Karakteristik Dominan

b. Kepemimpinan Organisasi

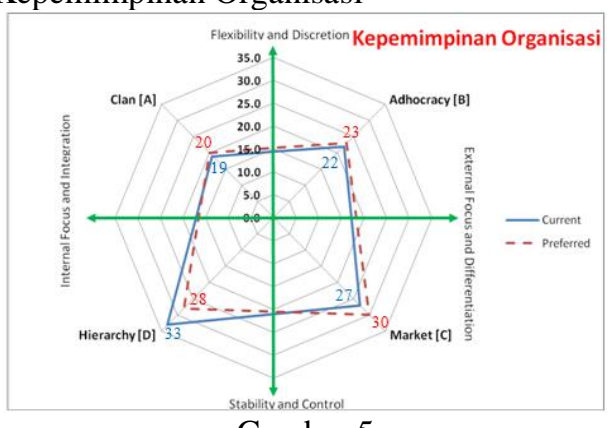

Gambar 5

Diagram radar Kepemimpinan Organisasi c. Pengelolaan Karyawan

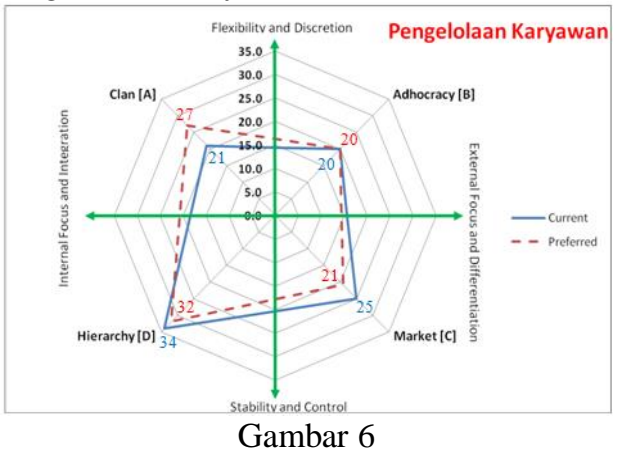

Diagram radar Pengelolaan Karyawan d. Perekat Organisasi

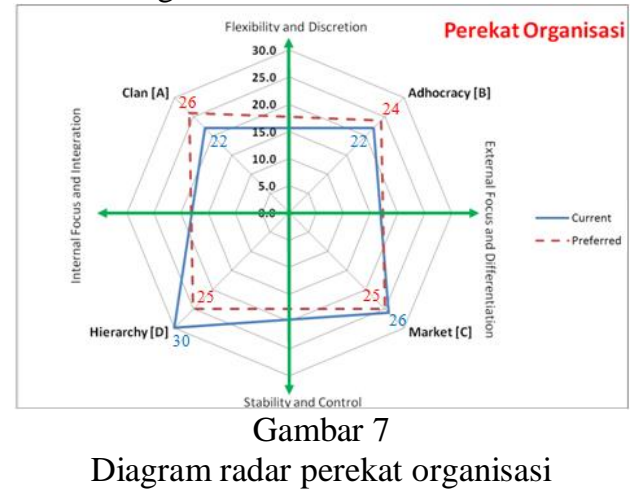

Diagram radar perekat organisasi 
e. Penekanan Strategis

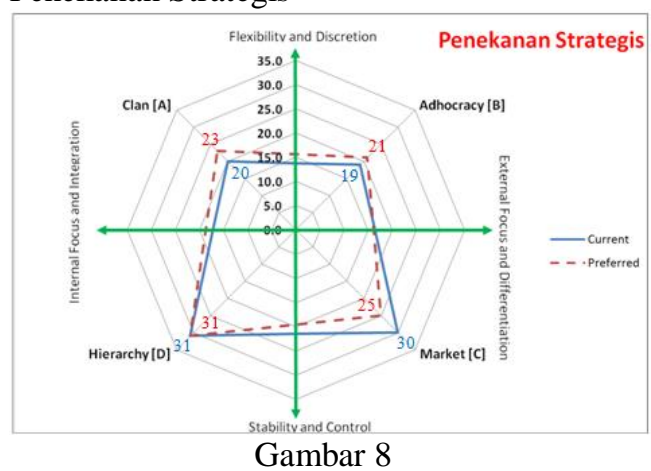

Diagram radar penekanan strategis

f. Kriteria Sukses

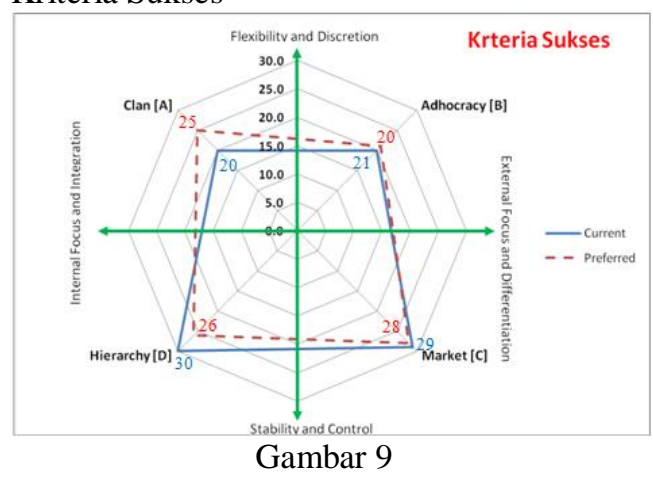

Diagram radar Kriteria Sukses

g. Profil Keseluruhan

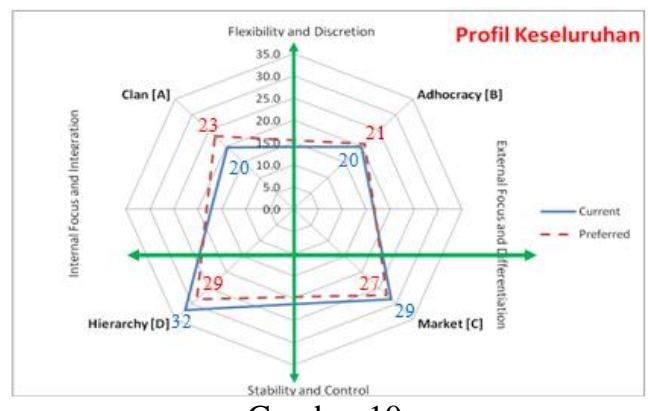

Gambar 10

Diagram radar Profil Keseluruhan

\section{Strategi Peningkatan kualitas Sumber Daya} Manusia pada PT. JKS Bali

strategi yang dapat dilakukan guna meningkatkan Sumber Daya Manusia PT. JKS Bali berdasarkan pada enam dimensi utama, yaitu :

a. Kepemimpinan Organisasi : Menerapkan kepemimpinan organisasi yang lebih fleksible namun tidak juga melanggar aturan

b. Pengelolaan Karyawan : melakukan pengelolaan karyawan yang lebih mengutamakan kerja sama tim, kesepakatan, partisipasi semua karyawan, lebih fokus pada pengelolaan intern perusahaan. c. Perekat Organisasi : mengurangi formalitas aturan aturan yang mendasari perekat organisasi.

d. Penekanan Strategis : fokus pada internal perusahaan dan mengurangi fokus pada persaingan pasar

e. Kriteria Sukses : menekankan kriteria sukses pada pengembangan SDM, kondisi internal perusahaan, kerja tim dan komitmen serta kepedulian akan sesama karyawan.

\section{SIMPULAN DAN SARAN \\ Simpulan}

Dari hasil analisis Budaya Organisasi pada PT. JKS Bali dengan OCAI maka dapat ditarik simpulan :

1. Secara keseluruhan Profil Budaya Organisasi PT. JKS Bali saat ini (current) dan yang diharapkan (preferred) masih didominasi oleh tipe budaya hierarchy dan market dengan gap sebesar 3\%, maka tidak dibutuhkan perubahan budaya organisasi yang signifikan. Namun jika dilihat lebih detail terhadap keenam dimensi, ada lima dimensi yang menunjukan gap lebih dari 5\% sehingga memerlukan perubahan budaya organisasi sebagai strategi peningkatan SDM pada perusahaan tersebut. Kelima dimensi tersebut adalah Kepemimpinan Organisasi, Pengelolaan Karyawan, Perekat Organisasi, Penekanan Strategis dan Kriteria Sukses.

2. Strategi yang diperlukan untuk meningkatkan kualitas Sumber Daya Manusia pada PT. JKS Bali berdasarkan pada enam dimensi utama, yaitu :
a. Kepemimpinan
Organisas Menerapkan kepemimpinan organisasi yang lebih fleksible namun tidak juga melanggar aturan

b. Pengelolaan Karyawan : melakukan pengelolaan karyawan yang lebih mengutamakan kerja sama tim, kesepakatan, partisipasi semua karyawan, lebih fokus pada pengelolaan intern perusahaan.

c. Perekat Organisasi : mengurangi formalitas aturan aturan yang mendasari perekat organisasi.

d. Penekanan Strategis : fokus pada internal perusahaan dan mengurangi fokus pada persaingan pasar

e. Kriteria Sukses : menekankan kriteria sukses pada pengembangan SDM, kondisi internal perusahaan, kerja tim 
dan komitmen serta kepedulian akan sesama karyawan.

\section{Saran}

1. Untuk meningkatkan kinerja SDM pada PT. JKS Bali perlu melakukan perubahan budaya organisasi pada keenam dimensi utama seperti dijelaskan pada kesimpulan.

2. Dalam penelitian berikutnya yang serupa dapat dilakukan dengan membandingkan budaya organisasi dari beberapa perusahaan kontraktor, antara lain dapat berupa perbandingan budaya organisasi pada perusahaan yang lebih sukses sebagai acuan bagi perusahaan yang ingin melakukan strategi peningkatan Sumber Daya Manusia.

\section{DAFTAR PUSTAKA}

Alwi, S. (2012) Manajemen Sumber Daya Manusia Strategi Keunggulan Kompetitif. Edisi kedua. Yogyakarta : BPFE-Yogyakarta

Anonim. (2015) Ipsative Item. [online]. [dikutip 2015 Juli 27] Available from

URL: http://www.psychometrictest.org.uk/i psative-items/.

Bagus, D. (2009) Teori Budaya organisasi. [online] April. [dikutip 2014 Oktober 19] Available from : URL: http://jurnalsdm.blogspot.com/2009/04/teoribudaya-organisasi.html

Brahmasari, I. A. \& Suprayetno, A. (2008) Pengaruh motivasi kerja, kepemimpinan dan Budaya Organisasi terhadap kepuasan kerja karyawan serta dampaknya pada kinerja perusahaan (studi kasus pada PT. Pei Hai International Wiratama Indonesia). Vol.10 no.2 : p. 124-135

Brockmann, C. \& Dohren, T. (2006) Measuring Cultural Dimensions in the German Construction Industry. Bremen : Hochschule Bremen

Cameron, K. S. \& Quinn, R. E. (2011) Diagnosing and Changing Organizational Culture. Third Edition. San Francisco : Jossey-Bass

Ed's-HRM. (2008) Teknik Pengelolaan Sumber Daya Manusia. [online],
April. [dikutip 2014 September 29]

Available from : URL: http://epsmanajemensdm.blogspot.co $\underline{\mathrm{m} / 2008 / 04 / \text { pengelolaan-sumber-daya- }}$ manusia.html.

Ellitan, L. 2002 Praktik-praktik Pengelolaan Sumber Daya Mausia dan Keunggulan Kompetitif Berkelanjutan, Vol.4 : 68

Enifah, E. 2012. "Strategi Peningkatan Kualitas Sumber Daya Manusia (SDM) Sebagai Upaya memaksimalkan produktivitas Perusahaan" (skripsi). Semarang: Institut Agama Islam Negeri Walisongo.

Erkutlu, H. (2008) Emerrald Insight : The Impact of transformational leadership on organizational and leadership effectiveness. Vol. 27 lss 7 : pp. $708-$ 726

Hofstede, G. \& Hofstede, G. J. (2012) Dimensions of National Cultures. [online]. [dikutip 2014 November 11] Available from : URL: http://geerthofstede.nl/dimensions-ofnational-cultures.

Husnawati, A. 2006. "Analisis pengaruh kualitas kehidupan kerjaterhadap kinerja karyawan dengan komitmen dan kepuasan kerja sebagai intervening variabel” (tesis). Semarang: Universitas Diponegoro.

Igo, T. \& Skitmore, M. (2006) Emerald Insight : Diagnosing the organizational culture of an Australian engineering consultancy using the competing values framework. Vol.6 lss 2 : pp. 121 139

Lang, K. K. 2012. BAB VIII Memahami Kualitas Sumber Daya Manusia. (artikel online), November, [dikutip 2015 Juli 14]. Available from : URL: http://kanakloeman.blogspot.com/201 2/11/bab-viii-memahami-kualitassumber-daya.html

Liu, A. M. M., Shuibo, Z. \& Meiyung, L. (2006) Emerrald Insight : A Framework for assessing 
organizational culture of Chinese construction enterprises. Vol. 13 lss 4 : pp. $327-342$

Moen, T. R. 2007. "An Examination of the Partial Ipsative and Work-Related Personality Test Shapes Admin : Reliability and Validity" (tesis). Norway: University of Oslo

Nummelin, J. (2006) Measuring Organizational Culture in Construction Sector - finish sample. Espoo : VTT Technical Research Centre of Finland

Oney-Yazici, E., Giritli, H., Topcu-Oraz, G. \& Acar, E. (2007) Organizatinal Culture : the case of Turkish construction industry. Vol.14 lss 6 : pp. 519-513

Reifman,A. and Keyton,K. (2010). Winsorize. In N. Salkind (Ed.) (ed.) Encyclopedia of Research Design. Thousand Oaks: SAGE Publications, Inc.

Sheskin,D. J. (2010). Outlier. In N. Salkind (Ed.). (ed.) Encyclopedia of Research Design. Thousand Oaks: SAGE Publications, Inc.

Tika, H. M. P. (2014) Budaya Organisasi dan Peningkatan Kinerja Perusahaan. PT. Bumi Aksara, Jakarta

Tim ISO 9001 : 2008 dan Tim P2K3. 2009. Pedoman Sistem Manajemen. No. Dok : PMO-JKSB-01. PT. Jaya Kusuma Sarana Bali

Tjahyanti, S. 2011. Peran Budaya organisasi dalam meningkatkan kinerja organisasi. Jakarta : STEI Trisakti

Ulwan, M.N. 2014. Teknik Pengambilan sampel dengan metode purposive sampling. (artikel online), Februari, [dikutip 2014 Oktober 1]. Available from : URL: http://portalstatistik.blogspot.com/2014/02/teknik -pengambilan-sampel-dengan$\underline{\text { metode.html }}$ 